\title{
Isotope Analysis Reveals Differential Impacts of Artificial and Natural Afforestation On Soil Organic Carbon Dynamics in Abandoned Farmland
}

Dongrui Di ( $\square$ didongrui@163.com)

Sophia University: Jochi Daigaku

Guangwei Huang

Sophia University

\section{Research Article}

Keywords: soil carbon stock, vegetation restoration, soil aggregate, soil respiration, 13C, 14C

Posted Date: October 1st, 2021

DOI: https://doi.org/10.21203/rs.3.rs-238894/v2

License: (c) (1) This work is licensed under a Creative Commons Attribution 4.0 International License.

Read Full License

Version of Record: A version of this preprint was published at Plant and Soil on November 26th, 2021. See the published version at https://doi.org/10.1007/s11104-021-05243-x. 
1 Title: Isotope analysis reveals differential impacts of artificial and natural

2 afforestation on soil organic carbon dynamics in abandoned farmland

3

4 Authors and Affiliations:

5 Dong-Rui Di, Guang-Wei Huang*

6 Graduate School of Global Environmental Studies, Sophia University, Tokyo

$7 \quad 102-8554$, Japan

8

$9 \quad$ Dong-Rui Di

10 didongrui@163.com

11

12

13

Guang-Wei Huang

huanggwx@sophia.ac.jp

*Corresponding authors: Guang-Wei Huang,huanggwx@ sophia.ac.jp

Tel/FAX: + 81-3-32384667

\section{Abstract:}

Backgrounds A multitude of studies have applied different methods to study the dynamics of soil organic carbon (SOC), but the differential impact of artificial and natural afforestation on SOC dynamic are still poorly understood.

Methods and aims We investigated the SOC dynamics following artificial and natural afforestation in Loess Plateau of China, characterizing soil structure and 
stoichiometry using stable isotope carbon and radiocarbon models. We aim to compare SOC dynamics, clarify SOC source under different afforestation, examine comparability of the study areas and find how soil aggregate size classes control SOC dynamics, finally to evaluate effect of reforestation project.

Results The $0-10 \mathrm{~cm}$ and $10-20 \mathrm{~cm}$ SOC stocks were significant higher than other two land-use system. At other depths, there is no significant difference among the three land-use system. Total top soil SOC stocks, C:N and C:P of differently sized soil aggregates significantly increased following afforestation. ${ }^{13} \mathrm{C}$ results and Radiocarbon models indicated that the SOC decomposition rate and new SOC input rate were lower under natural afforestation than artificial afforestation.

Conclusions Afforestation can accumulate SOC in top soils mainly resulting from in topsoil changing. SOC resource is mainly from macroaggregate formation provided by fresh plant residues. SOC loss from soil respiration was derived from microaggregates during afforestation. The "space-for-time substitution" method is suitable for comparability of the study areas.

Keywords: soil carbon stock; vegetation restoration; soil aggregate; soil respiration; ${ }^{13} \mathrm{C} ;{ }^{14} \mathrm{C}$ 


\section{Introduction}

Soil contains vast and dynamic pools of organic carbon that are fundamental for maintaining the balance of atmospheric $\mathrm{CO}_{2}$ concentrations (Lal 2004; Post et al. 1982).The soil organic carbon (SOC) pool and its dynamics are important properties of ecosystems (Schmidt et al. 2011). A multitude of studies report ecosystem changes significantly affect SOC pool and decomposition rate (Deng et al. 2016; Don et al. 2011; Snell et al. 2015; Wei et al. 2013; Zhang et al. 2015).

The Loess Plateau is the one of the largest geographic units in China. Rapid population growth combining with climate and environmental conditions in the area have resulted in severe soil erosion in the Loess Plateau (Shi et al. 2017). Since 1950s, great attention has been paid to control the severe soil erosion in the Loess Plateau. From 1950s to mid-1960s, the principle soil conservation strategies were terracing on cultivated slopes and planting trees on uncultivated slopes. During the mid-1960s and the late 1970s, warp land dam and terracing became the most popular soil conservation strategies. From late 1970s to late 1990s, terracing became the first principle soil conservation strategy and natural rehabilitation appeared in some places (Zhou et al. 2013). The Grain for Green project was implemented in 1999 to halt soil erosion and promote ecological restoration in the region. As part of this project, both natural and artificial afforestation have been promoted as methods of ecological restoration (Shi et al. 2011).

Human ecosystem interventions such as deforestation and afforestation, can cause rapid and persistent changes in vegetation and soil. Wei et al. (2013) found SOC 
stocks decreased most rapidly during the first 4 years of cropland cultivation after deforesting, but Rytter (2016) reported that SOC pools were generally unchanged after five years of Salicaceae growth during afforestation of former agricultural land. Natural change refers to the dynamic nature of ecosystem succession. Studies indicate that natural regeneration is slow and patchy with low species diversity (Blackham et al. 2014), and factors controlling SOC accumulation differed along vegetation succession (Liu et al. 2015).

Previous studies have applied different methods (e.g. space-for-time substitution, stable isotope analysis) to study SOC dynamics and have successfully answered questions related to soil structure and organic matter dynamics (Marin-Spiotta et al. 2009; Qiu et al. 2015). However, these previous studies mainly focused on natural ecosystem restoration, without considering the effects of artificial restoration. Furthermore, although Deng et al. (2016) have investigated the SOC turnover during natural succession, SOC dynamics in stable post-succession communities (climax community) following afforestation remain unstudied.

In this study, we combined (1) a time dependent steady-state box model based on radiocarbon $\left({ }^{14} \mathrm{C}\right)$ to estimate $\mathrm{SOC}$ decomposition rates in different land-use systems; (2) a natural abundance stable carbon isotope $\left({ }^{13} \mathrm{C}\right)$ study to quantify old and new carbon turnover during both natural and artificial afforestation; (3) measures of change of SOC stock at different depth and soil aggregate-associated organic carbon (OC) \& stoichiometry to investigate contribution of SOC change and the sensitivity and efficiency of soil aggregate-associated organic carbon with afforestation; and (4) 
long-term field monitoring of soil respiration to assess SOC loss. We aim to compare SOC dynamics under both natural and artificial afforestation, clarify SOC source during afforestation period, examine comparability of the study areas and find how soil aggregate size classes control SOC dynamics, finally to evaluate effect of reforestation project.

\section{Materials and methods}

\subsection{Study site}

The study site consisted of semi-arid forests located on Mt. Gonglushan, near Yan'an city in Shaanxi province, China $\left(36^{\circ} 25.40^{\prime \prime} \mathrm{N}, 109^{\circ} 31.53^{\prime \prime} \mathrm{E} ; 1245-1395 \mathrm{~m}\right.$ a.s.1.). On the Loess Plateau, precipitation and forest cover gradually decrease to the northwest, and our study site is located in the forest-grassland transition zone (Shi et al. 2014).The 40-year averages (1971-2010) of annual precipitation and annual mean air temperature were $504.7 \mathrm{~mm}$ and $10.1^{\circ} \mathrm{C}$, respectively (Shi et al. 2012a). The soils are classified as Calcic Cambisols, which are derived from silt textured loess parent materials (Wei et al. 2013).

\subsection{Field investigation and sampling}

We obtained estimates of the recovery periods of different communities from vegetation surveys from the 1950s to the early 2000s (Chen 1954; Fan et al. 2006; Zou et al. 2001) and records from local farmers and government (Tateno et al. 2007; Wang et al. 2010). These results have been accepted and used widely (Deng et al. 2016; Qiu et al. 2015). The study examined two different types of afforestation: natural vegetation restoration from abandoned farmland to natural forest dominated 
by Quercus liaotungensis Koidz ( 80 years) (NQ) and artificial restoration from abandoned farmland to plantation dominated by Robinia pseudoacacia L. ( 40 years) (AR). We compared these restoration types to a control site of abandoned farmland that remained unforested (AF). The three ecosystems were at least $3 \mathrm{~km}$ apart. To minimize the effects of area conditions on experimental results, we selected study areas with similar topography, land-use history, and soil type. Five $20 \mathrm{~m} \times 20 \mathrm{~m}$ plots were established along the slope within each land use system for avoiding topographic influence: the upper position located on the top of the slope, the upper-middle position located between upper and middle positions, the middle position located on the middle of slope, the bottom-middle position located between bottom and middle positions and the bottom position located in the gully and adjacent area to the slope.

Plots were spaced approximately 50m apart in each land-use system. Meanwhile, each plot was at least 40m from land-use system boundary to minimize edge effects.

We then dug five $20 \mathrm{~cm}$-deep pits for topsoil sampling at the four corners and the center in each plot, and took three soil bulk density (BD) samples. BD was measured at $0-20 \mathrm{~cm}$ in each subplot using a stainless steel cutting ring $(5 \times 5 \mathrm{~cm})$. The soil cores were dried at $105^{\circ} \mathrm{C}$ for $24 \mathrm{~h}$. Five soil samples $(0-20 \mathrm{~cm})$ were collected from the five pits in each plot, and the collected samples were mixed to form one homogeneous sample for analysis of $\delta^{13} \mathrm{C},{ }^{14} \mathrm{C}$, and aggregate size distribution. Three aggregate-size classes were manually fractionated through dry sieving of fresh soil samples on a series of two sieves $(0.25$ and $0.053 \mathrm{~mm})$ as follows: macroaggregates $(>0.25 \mathrm{~mm})$, microaggregates $(0.25-0.053 \mathrm{~mm})$ and silt \& clay $(<0.053 \mathrm{~mm})$. Fresh soil samples 
were dry sieved because wet sieving compromised the in situ link between the aggregates obtained and their indigenous biota. Furthermore, wet sieving could cause inaccurate evaluation of soil organic carbon (Jiang et al. 2014). The subsamples of each aggregate fraction were used for soil organic carbon (SOC), total nitrogen $(\mathrm{N})$, and total phosphorous (P) analysis. Each aggregate fraction was oven dried at $100^{\circ} \mathrm{C}$ and weighed to determine its proportion of total soil weight.

Meanwhile, SOC stock by investigation in deeper layers (0-1m) in June 2021. Totally, 45 soil profile were obtained for the investigation of $0-1 \mathrm{~m}$ soil layers: 5 pits/ plot $\times 3$ plots/ land-use system $\times 3$ land-use system. Close to every topsoil sampling pits, the soil samples representing depths of $0-10 \mathrm{~cm}, 10-20 \mathrm{~cm}, 20-30 \mathrm{~cm}, 30-50 \mathrm{~cm}$, 50-100 $\mathrm{cm}$ were collected using a soil sampling auger $(5-\mathrm{cm}$ diameter) considering distribution of root systems (Shi et al. 2011; Tateno et al. 2007). The SOC, TN and bulk density of 0-1 m soil profiles were measured.

Additionally, the paired investigation site was set up in same land-use system with at least $3 \mathrm{~km}$ distance between the paired sites ((NQ \& paired NQ; AR \& paired AR; AF \& paired AF) for comparing soil characters of over $3 \mathrm{~km}$-distance sites in same land-use system in June 2021. The soil samples representing depths of 0-10 cm and 10-20 $\mathrm{cm}$ were collected using a soil sampling auger $(5-\mathrm{cm}$ diameter $)$ for determining soil characters including soil organic carbon (SOC), total nitrogen $(\mathrm{N})$, total phosphorous (P), fast potassium (K), $\mathrm{pH}$ and bulk density (BD).

\subsection{Laboratory analysis}

Soil organic carbon (SOC), total nitrogen $(\mathrm{N})$, total phosphorous $(\mathrm{P})$ and fast 
154

155

potassium (K) were measured using a TOC VWP (Shimadzu, Japan), 2300 kjeltec analyzer unit (FOSS TECATOR, Sweden), and ICP-AES (Spectro, Analytical Instruments, Germany), respectively. Soil $\mathrm{pH}$ was determined using a soil/water ratio of 1:2.5 (PHSJ-4A pH acidometer, Shanghai, China). Soil organic carbon stock was calculated as the product of soil bulk density and SOC concentration.

Soil samples for $\delta^{13} \mathrm{C}$ analyses were pretreated with excess $1 \mathrm{~mol} \mathrm{~L}^{-1} \mathrm{HCl}$ to remove carbonates at room temperature, then rinsed and freeze dried for at least $24 \mathrm{~h}$ and ground into fine powder over $100 \mu \mathrm{m}$ meshes. Litters was washed with distilled water, then freeze-dried and ground into fine powder for measurement. The natural abundance of $\delta^{13} \mathrm{C}$ values in the soil organic matter and litter was analyzed with an Elemental Analyser (Eurovector) coupled to an isotope Ratio Mass Spectrometer (Delta plus, Thermo Fisher Scientific, USA) at the State key laboratory of Loess and Quaternary Geology at the Institute of Earth Environment, Chinese Academy of Sciences. Variation in the ${ }^{13} \mathrm{C} /{ }^{12} \mathrm{C}$ was reported relative to the Vienna PDB standard, and is expressed as:

$\delta(\% 0)=\left(\frac{R_{\text {sample }}}{R_{\text {standard }}}-1\right) \times 1000$

Where $R_{\text {sample }}$ is the ${ }^{13} \mathrm{C} /{ }^{12} \mathrm{C}$ ratio of the sample and $R_{\text {standard }}$ is the ${ }^{13} \mathrm{C} /{ }^{12} \mathrm{C}$ ratio in the PDB standard.

The soil samples were pretreated for ${ }^{14} \mathrm{C}$ analyses as standardized by Zhou et al. (1992). Measurement of ${ }^{14} \mathrm{C}$ in soil organic matter was carried out at the Xi'an Accelerator Mass Spectrometry Center in the Institute of Earth Environment, Chinese Academy of Science. Cryogenically purified $\mathrm{CO}_{2}$ was converted to the target using 

efflux.

the hydrogen-iron reduction method. This method was described in detail by Zhu et al.

\subsection{Measurement of soil respiration}

Soil respiration was measured using an automated soil $\mathrm{CO}_{2}$ flux system (LI-8100, LI-COR, USA) equipped with a portable chamber (Model 8100-103). A PVC collar (20.3 cm in diameter and $10 \mathrm{~cm}$ in height) was inserted into the forest floor to a depth of $2.5 \mathrm{~cm}$ at each sampling point, approximately two months before the first measurements. Small litter and branches were left in the collar while large items were removed. All collars were left at the respective site for the entirety of the study period.

Soil respiration was measured over the 4-year period from 14 June 2010 to 20June 2014, approximately once every 30 days during April-October (growing season), and once every 45 days in other months (dormant season). The measurements were conducted between 8:30 and 11:30 local time on each sampling day. In each plot, five $5 \mathrm{~m} \times 5 \mathrm{~m}$ subplots were established at the four corners and the center. The PVC collars were installed in the center of each subplot for measurements of soil $\mathrm{CO}_{2}$

\subsection{Data analysis}

Soil OC stocks were calculated as follow:

Soil $O C$ stocks $\left(\mathrm{kg} \mathrm{m}^{-2}\right)=\frac{D \times B D \times O C}{100}$

Where $\mathrm{D}$ is the thinness $(\mathrm{cm})$ of the soil layer, $\mathrm{BD}$ is the bulk density $\left(\mathrm{g} \mathrm{cm}^{-3}\right)$, and 
198

199

200

201

202

203

204

205

206

207

208

209

210

211

212

213

214

215

216

217

$\mathrm{OC}$ is the soil organic carbon concentrate $\left(\mathrm{g} \mathrm{kg}^{-1}\right)$ at $0-20 \mathrm{~cm}$.

Stocks of soil OC in each soil aggregate size class were calculated as:

Stocks of $O C_{i}\left(\mathrm{~kg} \mathrm{~m}^{-2}\right)=\frac{D \times B D \times w_{i} \times O C_{i}}{10000}$

Where $O C_{i}$ is the soil organic carbon concentration of the $i$ th aggregate size class $(\mathrm{g}$ $\mathrm{kg}^{-1}$ aggregate).

During the afforestation period, the decomposition rate constants $k_{1}\left(\mathrm{yr}^{-1}\right)$ was calculated by these models based on $\delta^{13} \mathrm{C}$ method: The proportions of new SOC $\left(f_{\text {new }}\right)$ and old SOC $\left(f_{\text {old }}\right)$ were estimated based on the mass balance equations (Del Galdo et al. 2003):

$$
f_{\text {new }}=\frac{\left(\delta_{\text {new }}-\delta_{\text {old }}\right) \times 100 \%}{\delta_{\text {veg }}-\delta_{\text {old }}}
$$

$f_{\text {old }}=100-f_{\text {new }}$

where $\delta_{\text {new }}$ is the $\delta^{13} \mathrm{C}$ value of the soil sample from current ecosystem, $\delta_{\text {old }}$ is the $\delta^{13} \mathrm{C}$ value of the soil sample prior to ecosystem succession and $\delta_{\text {veg }}$ is the $\delta^{13} \mathrm{C}$ value of the mixed litter of current vegetation. Decomposition rate constants $\left(k_{1}\right)$ of soil OC were estimated using the following equations(Marin-Spiotta et al. 2009):

$k_{1}=\frac{-\ln \left(C_{t} / C_{0}\right)}{t}$

Where $C_{0}$ is the initial SOC stock (SOC stock in the reference sites), $C_{t}$ is initial SOC stock remaining (old $\mathrm{C}$ stock) at time $\mathrm{t}$ (year) since ecosystem change.

For the long-term ecosystem, the decomposition rate constants $k_{2}\left(\mathrm{yr}^{-1}\right)$ was obtained through the bomb- ${ }^{14} \mathrm{C}$ model (Cherkinsky and Brovkin 1993; Torn et al. 2002; Trumbore 1993). The procedures were as follows (Tan et al. 2013): 
${ }^{14} \mathrm{C}$ data $(\mathrm{pMC})$ is defined as

$$
\operatorname{pMC}(\%)=\frac{\mathrm{A}_{\mathrm{SN}}}{\mathrm{A}_{\mathrm{ON}} \times \mathrm{e}^{\lambda(\mathrm{y}-1950)}} \times 100
$$

where $A_{S N}$ is the ${ }^{14} \mathrm{C} /{ }^{12} \mathrm{C}$ ratio of the sample corrected to a $\delta^{13} \mathrm{C}$ value of $-25 \%$ o to

222 account for the assumption that plants discriminate twice as much against ${ }^{14} \mathrm{C}$ as they

do against ${ }^{13} \mathrm{C}$, Aon is the ${ }^{14} \mathrm{C} /{ }^{12} \mathrm{C}$ ratio of the oxalic acid activity normalized to $\delta^{13} \mathrm{C}$

value of $-19 \%, \lambda=1 / 8267$ is based on the 5730 a half-life, and (y) is the year of

Oxalic measurement.

The SOC turnover times were estimated using a time dependent steady-state box

model. This assumes that variation in ${ }^{14} \mathrm{C}$ in a soil with time follows a first-order kinetic law, which the can be described by mass balance equation:

$$
C_{y} \times{ }^{14} C_{y}=C_{y-1} \times{ }^{14} C_{y-1} \times\left(1-k_{2}-\lambda\right)+I \times{ }^{14} C_{a t m_{y-l a g}}
$$

where $C$ is the organic carbon inventory of a soil sample $\left(\mathrm{g} \mathrm{C} \mathrm{m}^{-2}\right),{ }^{14} C$ is the pMC of a soil sample $(\%), k$ is the first order decomposition constant for homogeneous $\mathrm{C}$ pools $\left(\mathrm{a}^{-1}\right), \lambda$ is the ${ }^{14} C$ decay constant (1/8267), $I$ is the annual carbon input $\left(\mathrm{g} \mathrm{C} \mathrm{m}^{-2}\right.$ $\left.\mathrm{a}^{-1}\right),{ }^{14} \mathrm{C}_{\text {atm }}$ is the pMC of the atmosphere $\mathrm{CO}_{2}(\%)$, lag is the average number of years that atmospheric $\mathrm{CO}_{2}$ is retained in plant tissue before becoming part of the soil organic matter pool. At steady state, $C_{y}=C_{y-l}$ and $I=k C$, eq. (7) can be transformed into:

$$
{ }^{14} C_{y}={ }^{14} C_{a t m_{y-l a g}} \times k_{2}+{ }^{14} C_{y-1} \times\left(1-k_{2}-\lambda\right)
$$

The decomposition rate constant $k_{2}$ is obtained by matching the modeled and measured $p \mathrm{MC}$ for the year in which the soil was sampled based on ${ }^{14} C_{\text {atm }}$ adopt from curve of ${ }^{14} \mathrm{C}$ of atmospheric $\mathrm{CO}_{2}$. 
A method was proposed by Qiu et al. (2012) for assessing the relative

contribution of changes in aggregate amount and aggregate-associated OC concentrations to the total changes in $\mathrm{OC}$ stocks within each aggregate fraction. It was assumed that changes in $\mathrm{OC}$ stock within any particular aggregate fraction were caused both by changes in OC concentration in the fraction $\left(\mathrm{F}_{1}\right)$ and by changes in the mass of the fraction $\left(\mathrm{F}_{2}\right)$. It was also assumed that the mass that was gained or lost from an aggregate fraction due to ecosystem change had the same OC concentration as the rest of that fraction after ecosystem change. We therefore calculated the contribution of $F_{1}$ and $F_{2}$ to the total change in OC stock within an aggregate fraction as follows:

$$
\begin{aligned}
& F_{1}=\mathrm{M} \times \Delta \mathrm{C} \\
& F_{2}=\Delta \mathrm{M} \times \mathrm{C}
\end{aligned}
$$

where $F_{1}$ is the change in $\mathrm{OC}$ stock $\left(\mathrm{g} \mathrm{m}^{-2}\right)$ within an aggregate fraction due to changes in aggregate-associated OC concentrations, $F_{2}$ is the change in the $\mathrm{OC}$ stock $\left(\mathrm{gm}^{-2}\right)$ within an aggregate fraction due to changes in the mass of the aggregate fraction, $\Delta \mathrm{M}$ is the change in the mass of a particular fraction $\left(\mathrm{kg} \mathrm{m}^{-2}\right), \mathrm{M}$ is the initial mass of the aggregate fraction $\left(\mathrm{kg} \mathrm{m}^{-2}\right)$ before ecosystem change, $\mathrm{C}$ is the final $\mathrm{OC}$ concentration of the aggregate fraction $\left(\mathrm{g} \mathrm{kg}^{-1}\right)$ after ecosystem change and $\Delta \mathrm{C}$ is the change in the $\mathrm{OC}$ concentration of the aggregate fraction $\left(\mathrm{g} \mathrm{kg}^{-1}\right)$ due to ecosystem change.

\subsection{Calculation of Annual soil $\mathrm{CO}_{2}$ emissions}

Annual soil $\mathrm{CO}_{2}$ emissions were estimated by interpolating the average $\mathrm{CO}_{2}$ flux 
rate between sampling dates, and computing the sum of the products of the average flux rate and the time between respective sampling dates for each measurement period(Shi et al. 2014; Shi et al. 2012b; Sims and Bradford 2001)as follows:

$$
R=\sum F_{m, n} \Delta t_{n}
$$

Where $\Delta t_{n}=t_{n+1}-t_{n}$, which is the number of days between each field measurement within the year; $R$ is total soil $\mathrm{CO}_{2}$ emitted in the measurement period, and $F_{m, n}$ is the average $\mathrm{CO}_{2}$ flux rate over the interval $t_{n+1}-t_{n}$ recorded by the LI-8100 Soil $\mathrm{CO}_{2}$ Flux System.

\subsection{Statistical analyses}

One-way Analysis of Variation (ANOVA) with Pearson's test was performed to examine the difference between period of artificial and natural afforestation in topsoil SOC decomposition rate constants $\left(\mathrm{k}_{1}\right)$ and new SOC input rate calculated with a ${ }^{13} \mathrm{C}$ model, and difference of contribution of $F_{1}$ and $F_{2}$ to the total change in SOC stock within an aggregate fraction between artificial and natural afforestation. Repeated measures ANOVA (RMANOVA) was applied to test the significance of SOC stocks at different soil depth, SOC in different soil aggregate size classes, soil aggregate size class distributions, $\mathrm{C}: \mathrm{N}$ and $\mathrm{C}: \mathrm{P}$ of different soil aggregate size classes, mean annual soil $\mathrm{CO}_{2}$ emission, SOC decomposition rate constants $\left(\mathrm{k}_{2}\right)$ calculated with a ${ }^{14} \mathrm{C}$ model among the three land use systems using Tukeys's HSD test at $p<0.05$. All differences were evaluated at the 5\% significance level. 


\section{Results}

\subsection{The SOC stocks and contents}

The Fig 1 showed the soil organic carbon (SOC) stock (a) and soil organic carbon contents at each depth of the three different land-use systems, AF: abandoned farmland; AR: artificial afforestation (plantation of Robinia pseudoacacia L); NQ: natural afforestation (natural forest - Quercus liaotungensis Koidz). The SOC stock and content in $0-10 \mathrm{~cm}$ soil significantly increased with both artificial afforestation dominated by plantation of Robinia pseudoacacia L (AR) and natural afforestation dominated by natural forest Quercus liaotungensis Koidz (NQ).

Nevertheless, SOC stocks in $0-10 \mathrm{~cm}$ soil for artificial afforestation was significant lower than for natural afforestation. And the SOC stock and content in $10-20 \mathrm{~cm}$ soil in NQ is significantly higher than other two land-use systems, but there are no significant differences between in AR and AF. At other depths, there are no significant differences among the three land-use system. The results indicated accumulation of $0-1 \mathrm{~m}$ SOC was mainly from $0-20 \mathrm{~cm}$ topsoil changes under afforestation and was consistent with previous studies (Guillaume et al. 2015; Hiltbrunner et al. 2013; Song et al. 2016) .

\subsection{Aggregates organic carbon $(O C)$ stocks, size distribution and $C: N$ \& $C: P$}

Fig 2a shows the difference of different aggregate size organic carbon (OC) stocks in the three land-use systems. Under both artificial and natural afforestation, the OC stocks of macroaggregates and microaggregates significantly increased, but the OC stocks of silt \& clay were nearly 0 (far lower than for any other fraction), and 
could thus be considered a negligible part of total OC stocks. The OC stock of macroaggregates was significant higher than that of microaggregate in AR, but the OC stock of macroaggregate and microaggregate were nearly the same in NQ. Meanwhile, The OC stock of macroaggregate and microaggregate in NQ were respectively significant lower and higher than in AR (Fig. 2a).

Macroaggregates and microaggregates accounted for approximate $99 \%$ of the dry soil weight in the abandoned farmland. Under both artificial and natural restoration, the amount of soil in macroaggregates significantly increased, and microaggreagtes significantly decreased. There are no significant differences on the proportion of different size aggregate between in NQ and AR (Fig 2b). Furthermore, for both types of restorations, the amount of soils in silt \& clay was less than $1 \%$ and did not significantly change.

Both $\mathrm{C}: \mathrm{N}$ and $\mathrm{C}: \mathrm{P}$ of different aggregate classes significantly increased with both types of afforestation. Compared with other size aggregates, $\mathrm{C}: \mathrm{N}$ and $\mathrm{C}: \mathrm{P}$ of microaggregates become higher after afforestation. Additionally, $\mathrm{C}: \mathrm{N}$ and $\mathrm{C}: \mathrm{P}$ in NQ were significantly higher than AR, except for $\mathrm{C}: \mathrm{N}$ ratio of macroaggregates in NQ comparing with AR (Fig 3).

\subsection{Turnover of $\mathrm{SOC}$ and soil $\mathrm{CO}_{2}$ emissions}

Over the afforestation period, the SOC decomposition rate $\left(\mathrm{k}_{1}\right)$, and new SOC input rate $\left(\mathrm{k}_{2}\right)$ under artificial restoration were higher than natural restoration (Fig 4).

For the three land-use systems, the SOC decomposition rate $\left(\mathrm{k}_{2}\right)$ was highest $\left(2.6 \times 10^{-3}\right)$ in the natural forest ecosystem (Quercus liaotungensis Koidz). The $\mathrm{k}_{2}$ of 
abandoned farmland and plantation (Robinia pseudoacacia L.) were similar (Fig 5).

The amount of soil $\mathrm{CO}_{2}$ emissions across ecosystems was calculated from continuous measurements over 4 years. Both natural and artificial restoration significantly increased the amount of soil $\mathrm{CO}_{2}$ emissions, and the increased of amount of soil $\mathrm{CO}_{2}$ emissions was higher under natural restoration (NQ) than artificial restoration (AR) (Fig 6).

\subsection{Contribution of mass and OC content in different soil aggregate size}

The aggregate-model $\left(F_{1} \& F_{2}\right)$ results show that the changes in $F_{1} \& F_{2}$ under artificial and natural restoration were nearly the same, and $F_{1}$ and $F_{2}$ significantly increased and decreased respectively, for macroaggregate-OC after afforestation, but changes in $F_{1} \& F_{2}$ for macroaggregate-OC were more significant under natural afforestation (Fig 7 a, b). In addition, $F_{1}$ significantly increased and $F_{2}$ slightly decreased for microaggregate-OC (Fig $7 \mathrm{c}, \mathrm{d})$. The aggregate-model $\left(\mathrm{F}_{1} \& \mathrm{~F}_{2}\right)$ results indicated that increases in SOC stocks in macroaggregates and microaggregates under artificial and natural afforestation were mainly due to increases in SOC concentration rather than mass (Fig 7). The contribution of macroaggregate-OC concentration increases under natural afforestation was more significant than under artificial, but microaggregate-OC changes under natural and artificial afforestation were similar. Therefore, we concluded that macroaggregate-OC stock is the main contributing factor to changes in total OC stock. 


\section{Discussion}

\subsection{Afforestation evaluation for SOC accumulation}

Restoration effect is the most important for evaluating reforestation project. Actually this is very difficult to find primeval forest as undisturbed site for direct comparison, because in this region there is no primary forest due to more than 2000-years agricultural activity and semiarid climate. Until now the oldest secondary forest is about 200 years which is located in semi-humid region of Loess Plateau (Qiu et al. 2015). In this study, our results not only compared with other reforestation projects but also compared with 200-years secondary forest as "control" undisturbed sites for evaluating SOC accumulation under afforestation.

Laganiére et al. (2010) summarize afforestation project data for investigating the influence of afforestation in agricultural soils on SOC stocks by 120 sites and 189 observations globally. The study found that afforestation resulted in an increase in SOC stocks of $26 \%$ on average. In subtropical region, natural afforestation (secondary forest) and artificial afforestation in bare land increase $\sim 190 \%$ and $\sim 95 \%$ of $0-60 \mathrm{~cm}$ SOC stock respectively, but the afforestation still did not lead SOC stock to recover to level of undisturbed sites (primeval forest). The level of SOC stock in natural afforestation was only reach to $\sim 60 \%$ of primeval forest (Wang et al. 2017). In sub-alpine region, afforestation in pasture resulted in $13 \%$ increase of $0-80 \mathrm{~cm}$ total SOC stocks, but the $60 \%$ of increase was resulted from 0-10 cm topsoil (Hiltbrunner et al. 2013). Oppositely, the previous studies on deforestation as reference also can used to evaluate recovery of SOC stock after afforestation. Guillaume et al. (2018) 
globally synthesize the impacts on SOC stock of rainforest conversion to tree plantations on carbon stocks and dynamics and found plantations lead to SOC stocks $(0-50 \mathrm{~cm})$ decreased by $10 \%-32 \%$; van Straaten et al. (2015) indicated tropical deforestation for tree plantations decreased $0-300 \mathrm{~cm}$ SOC stocks by up to $50 \%$; Guillaume et al. (2015) showed SOC stocks $(0-60 \mathrm{~cm})$ decreased by $24 \%-42 \%$ under different plantations compared to the forest. The SOC stock reduction in plantations was significant down to topsoil $(0-30 \mathrm{~cm})$, but not when deeper layers were included. In this study, natural afforestation (NQ) and artificial afforestation (AR) in abandoned farmland land increase $43 \%$ and $14 \%$ of total SOC stock $(0-100 \mathrm{~cm})$ respectively, and the $80 \%$ of increase was resulted from $0-20 \mathrm{~cm}$ topsoil which was consistent with previous studies (Guillaume et al. 2015; Hiltbrunner et al. 2013). Comparing with 200-years secondary forest SOC stock ( 33 $\mathrm{Mg} \mathrm{ha}^{-1}$ in $0-10 \mathrm{~cm} ; \sim 16$ $\mathrm{Mg} \mathrm{ha}^{-1}$ in 10-20 cm) in semi-humid region of loess plateau (Qiu et al. 2015), natural afforestation in this study is reach up to the similar level. Additionally, our study also indicated SOC stocks $(0-50 \mathrm{~cm})$ in artificial afforestation (AR) was $30 \%$ lower than natural afforestation (NQ). This result also agrees with previous studies(Guillaume et al. 2015; van Straaten et al. 2015). In view of global afforestation projects or deforestation activities, we could conclude that afforestation in study area is effective for SOC accumulation, and natural afforestation is more significant than artificial.

\subsection{SOC source analysis based on aggregates and carbon isotope in topsoil}

A multitude of studies found that afforestation can lead to the accumulation of 
SOC mainly resulting from increase of SOC in topsoil, and the effects of land use change during vegetation restoration on SOC are mainly due to changes in OC input and C mineralization (Deng et al. 2016; Laganiére et al. 2010). The OC in soil physical fractions responds more sensitively and rapidly to land use change than the OC in bulk soils (Qiu et al. 2012; Wei et al. 2013); therefore, changes in aggregate-associated OC are regarded as fundamental processes for understanding the effects of vegetation restoration on SOC.

Stable isotope techniques provide an ideal tool for investigating the sources and dynamic of SOC based on the theory: the increase in proportion of new OC in soils could be attributed to the OC inputs from the new vegetation producing organic matter with different ${ }^{13} \mathrm{C} /{ }^{12} \mathrm{C}$ ratio (Marin-Spiotta et al. 2009). And Richter et al. (1999) reported that the rates of new soil OC increase represented the net effect of new OC input including litterfall, rhizo-deposition and hydrological leaching of dissolved OC and output with organic matter mineralization to soils. Deng et al. (2016) summarize that sources of SOC resulting from vegetation restoration: (1) vegetation restoration facilitated SOC accumulation from biomass input (Tang et al. 2010). Vegetation biomass resulting from aboveground leaf litter and belowground roots is the main source of organic matter input into the soil (Laganiére et al. 2010; Zhao et al. 2015); (2) vegetation restoration probably contributed to the formation of stable soil aggregates (An et al. 2010), thus facilitating physical protection of SOC within aggregates (Lal 2004). 

vegetation biomass resulting from aboveground leaf litter and belowground roots due to afforestation in no-plant abandoned farmland, but our ${ }^{13} \mathrm{C}$ result indicated old $\mathrm{C}$ decomposition and new $\mathrm{C}$ inputs during natural afforestation were significantly lower than during artificial afforestation (Fig 4); Meanwhile, the period of natural 421 afforestation ( $~ 80$ years) was twice as long as the period of artificial afforestation 422 ( 40 years). Though the new SOC input rate under natural afforestation was lower 423 compared to artificial afforestation, the decomposition rate under natural afforestation 424 was also lower, which may indicate higher SOC accumulation under natural 425 afforestation is not attributable only to higher net increases in the difference between 426 new SOC input and old SOC decomposition. less decomposed organic material, and had faster soil $\mathrm{C}$ turnover compared to micro-aggregates (Tisdall and Oades 1982). Some studies using ${ }^{13} \mathrm{C}$ technology also 430 confirm the theory and found the ${ }^{13} \mathrm{C}$ in aggregates is enriched with decreasing aggregate size class in forest and farmland soils and SOC in macro-aggregates is 432 younger and more labile than SOC in micro-aggregates (Liu et al. 2018a). That is 433 because that lower $\delta^{13} \mathrm{C}$ values have been linked to more recent litter inputs, while 434 higher $\delta^{13} \mathrm{C}$ values were related to older organic matter (Deng et al. 2016). All the 435 previous studies concluded that fresh plant residues are the main agent for macroaggregate formation (Six and Paustian 2014). 
SOC stocks were mainly due to increases in SOC concentration rather than mass in macroaggregates and microaggregates (Fig 7), and could conclude that macroaggregate-OC stock is the main contributing factor to changes in total SOC stock. Previous studies obtained a similar results (Liu et al. 2018b; Qiu et al. 2015). Combining with our and previous results, the studies confirms that SOC resource is mainly from macroaggregate formation provided by fresh plant residues. These results are also in accordance with previous observations

\subsection{SOC turnover and soil $\mathrm{CO}_{2}$ emission}

time since land use change has not been considered as a key parameter for the accumulation of SOC. In this study, the period of natural afforestation was twice as long as the period of artificial afforestation. Though the new SOC input rate under natural afforestation was lower compared to artificial afforestation, the decomposition rate under natural afforestation was also lower, which may indicate higher SOC accumulation under natural afforestation is not attributable only to higher net increases in the difference between new SOC input and old SOC decomposition. We could conclude that time since land use change is a more important factor determining the proportions of new and old OC in soil. Previous studies lend support to this hypothesis.

Not only climax forest but also other types of ecosystems in semiarid or arid region often maintain in stable stage for a long time (Fan et al. 2006) and the dynamics of SOC in the ecosystem could be considered as an ecosystem property (Schmidt et al. 2011). ${ }^{14} \mathrm{C}$ dating has been proven to be an ideal tool to study the 
dynamics of SOC from decadal to millennial timescales, which provides a direct measure of the time elapsed since carbon in organic matter was fixed from the atmosphere (Trumbore 1993). In this study, the steady-state box model of ${ }^{14} \mathrm{C}$ of SOC was applied to estimate the mean residence time (MRT) of SOC for the long-term ecosystem, providing a sensitive indicator to quantify the proportion of SOC derived from the atmosphere in recent years to centuries based on the rate of incorporation of the nuclear explosion before 1960s carbon tracer (Laskar et al. 2016; Torn et al. 2009). In our study, the result of the ${ }^{14} \mathrm{C}$ model suggested that the carbon decomposition rate was the lowest in the plantation (Robinia pseudoacacia L.) ecosystem, and was the same as abandoned farmland. The carbon decomposition rate was highest in the natural forest ecosystem (Quercus liaotungensis Koidz) (Fig 5). The model provided a direct evidence that higher accumulation of SOC under natural afforestation can be attributed to its longer restoration period rather than more rapid carbon turnover under natural afforestation compared to artificial afforestation. Therefore, our study suggests that longer recovery time could be more important for SOC accumulation following afforestation than any particular method of afforestation.

Additionally, soil respiration was always regarded as a kind of main pathway of soil OC loss (Shi et al. 2011). In this study, the result indicated that long-term soil $\mathrm{CO}_{2}$ emission during afforestation promoted SOC loss via soil respiration, especially for natural afforestation (Fig 6). Meanwhile, the analysis of soil stoichiometry in the study suggested that $\mathrm{C} / \mathrm{N}$ and $\mathrm{C} / \mathrm{P}$ ratios in microaggregates were consistently higher than in other fractions under afforestation (Fig 3). And Spohn and Chodak (2015) 
482

483

484

485

486

487

488

489

490

491

492

493

494

495

496

497

498

499

500

501

502

503

found that microorganisms increase their respiration rate with an increase in soil $\mathrm{C} / \mathrm{P}$ ratio and $\mathrm{C}$ concentration. Therefore, combining our results with previous studies, it was concluded that SOC loss from soil respiration was mainly originated from microaggregate resulting from higher $\mathrm{C} / \mathrm{P}$ ratio after afforestation, supporting the previous inference in terms of relationship between ecological stoichiometry and soil respiration (Spohn and Chodak 2015).

\subsection{Comparability of the study areas}

The comparability of the study areas is the central question in this study. Previous studies in this area also demonstrate topography greatly influence soil characters due to the hilly-gully topography (Shi et al. 2017; Tateno et al. 2017; Zhang et al. 2013). The studies found that the SOC, TN and other characters were significantly different along the hill slope. Therefore, in this study five $20 \mathrm{~m} \times 20 \mathrm{~m}$ plots were established along the slope within each land use system for avoiding topographic influence (detailed description of method in 2.2. Field investigation and sampling).

Additionally, the study area located in semiarid Loess Plateau, and rainfed agricultural areas are mainly distributed in the study areas and agricultural lands in this area are mostly on slopes (An et al. 2014). A lot of studies and documents reported that the semiarid region is always regarded as an entirety by reforestation project due to the same agriculture model, soil type, geological and climate condition of this region (He et al. 2014; Yamamoto and Endo 2014; Yamanaka et al. 2014), and which is resulted in same land-use history. Base on high-density forest resources 
504

505

506

507

508

509

510

511

512

513

514

515

516

517

518

519

520

521

522

523

524

525

inventory data and field measurements, Cui et al. (2015) and Li et al. (2017) analyses the carbon stock distribution patterns of forest ecosystems in Shaanxi Province of China (this study area located in the center of the province) and found spatial heterogeneity of soil characters and forest structure is not significant under the same forest age and tree species in semiarid region.

For a direct evidence, an invagination on characterization of the soils in the areas was carried out. The paired investigation site was set up in same land-use system with at least 3-km distance between the paired sites for comparing soil characters of over $3 \mathrm{~km}$-distance sites in same land-use system. The characterization of the soils was presented in table 1 including SOC, TN, TP, fast $\mathrm{K} . \mathrm{pH}$ and $\mathrm{BD}$. The results showed soil characters between paired sites such as NQ \& paired NQ, AR \& paired AR, and AF \& paired AF were not significant different, and then indicated homogeneity of soil characters in this area. The found was agreed with previous observations

In this study area, some studies using "space-for-time substitution" method has been published. The table 2 summarize the related information. All the previous studies more focused on edge effects of ecological transitional zone and topographic influence without spatial heterogeneity due to the high homogeneity of soil under same vegetation in this area. Therefore, in published studies the distances among different vegetation/ land-use types was required a reasonable long distance such as at least $3 \mathrm{~km}$ for minimizing edge effects of ecological transitional zone. Therefore, we could conclude that the method especially for $\sim 3 \mathrm{~km}$ distance among different land-use systems is suitable for comparability of the study areas. 


\section{Conclusions}

In conclusion, afforestation in study area is effective for SOC accumulation, and natural afforestation is more significant than artificial, which is mainly resulting from in topsoil changing. Carbon isotope and soil aggregates models analyzed that SOC resource is mainly from macroaggregate formation provided by fresh plant residues. The SOC concentration of soil aggregates played a dominant role in determining the dynamics of SOC accumulation during afforestation period. Based on the analysis of soil aggregates, soil respiration, and aggregate stoichiometry, we concluded that SOC loss from soil respiration mainly originated from microaggregates during afforestation.

${ }^{13} \mathrm{C}$ and ${ }^{14} \mathrm{C}$ models proved effective tools that showed that recovery time is a key factor determining the accumulation of SOC following afforestation. Especially, the study confirm that"space-for-time substitution" method is suitable for comparability of the study areas.

\section{Acknowledgements}

We would like to thank Dr. Julia Monk at Yale University for her assistance with English language and grammatical editing. We also extended sincerely thank the three reviewers and Editor Dr. Lucas Silva for their valuable \& excellent comments and suggestions, respectively. This research has been supported by projects from Engineered Food Production for Sustainable Agriculture Systems, Grand-in Aid for Challenging Research (Pioneering, No.20K20358). 


\section{References}

549 An P, Inoue T, Zheng M, Eneji AE, Inanaga S (2014) Agriculture on the Loess Plateau.

An S, Mentler A, Mayer H, Blum WEH (2010) Soil aggregation, aggregate stability, organic carbon and nitrogen in different soil aggregate fractions under forest and shrub vegetation on the Loess Plateau, China. CATENA 81: 226-233. doi: https://doi.org/10.1016/j.catena.2010.04.002.

Blackham GV, Webb EL, Corlett RT (2014) Natural regeneration in a degraded tropical peatland, Central Kalimantan, Indonesia: Implications for forest restoration. Forest Ecol Manag $\quad 324$

8-15. doi: http://dx.doi.org/10.1016/j.foreco.2014.03.041.

Chen C (1954) The vegetation and its roles in soil and water conservation in the secondary forest area in the boundary of Shaanxi and Gansu provinces. Acta Phytoecologica et Geobotanica Sinica (in Chinese)(2): 152-223.

Cherkinsky AE, Brovkin VA (1993) Dynamics of radiocarbon in soils. Radiocarbon 35: $363-367$.

Cui G, Chen Y, Cao Y, An C (2015) Analysis on carbon stock distribution patterns of forest ecosystems in Shaanxi Province. Chinese Journal of Plant Ecology 39: $333-342$.

Del Galdo I, Six J, Peressotti A, Francesca Cotrufo M (2003) Assessing the impact of land-use change on soil $\mathrm{C}$ sequestration in agricultural soils by means of 
organic matter fractionation and stable $\mathrm{C}$ isotopes. Global Change Biol 9: 1204-1213. doi: 10.1046/j.1365-2486.2003.00657.x.

572 Deng L, Wang K-B, Chen M-L, Shangguan Z-P, Sweeney S (2013) Soil organic carbon storage capacity positively related to forest succession on the Loess Plateau, China. https://doi.org/10.1016/j.catena.2013.06.016.

Deng L, Wang K, Tang Z, Shangguan Z (2016) Soil organic carbon dynamics following natural vegetation restoration: Evidence from stable carbon isotopes (813C). Agriculture, Ecosyst Environ 221: 235-244. doi: http://dx.doi.org/10.1016/j.agee.2016.01.048.

Don A, Schumacher J, Freibauer A (2011) Impact of tropical land-use change on soil organic carbon stocks - a meta-analysis. Global Change Biol 17: 1658-1670. doi: 10.1111/j.1365-2486.2010.02336.x.

Fan W-Y, Wang X-A, Guo H (2006) Analysis of plant community successional series in the Ziwuling area on the Loess Plateau. Acta Ecologica Sinica 26: 706-714.

Guillaume T, Damris M, Kuzyakov Y (2015) Losses of soil carbon by converting tropical forest to plantations: erosion and decomposition estimated by $\delta 13 \mathrm{C}$. Global Change Biol 21: 3548-3560. doi: https://doi.org/10.1111/gcb.12907.

Guillaume T, Kotowska MM, Hertel D, Knohl A, Krashevska V, Murtilaksono K, Scheu S, Kuzyakov Y (2018) Carbon costs and benefits of Indonesian rainforest conversion to plantations. Nat Commun 9: 2388. doi: 10.1038/s41467-018-04755-y. 
592

593

594

595

596

597

598

599

600

601

602

603

604

605

606

607

608

609

610

611

612

613

He J-F, Guan J-H, Zhang W-H (2014) Land Use Change and Deforestation on the Loess Plateau. In: A Tsunekawa, G Liu, N Yamanaka, S Du (eds) Restoration and Development of the Degraded Loess Plateau, China. Springer Japan, Tokyo.

Hiltbrunner D, Zimmermann S, Hagedorn F (2013) Afforestation with Norway spruce on a subalpine pasture alters carbon dynamics but only moderately affects soil carbon storage. Biogeochemistry 115: 251-266. doi: 10.1007/s10533-013-9832-6.

Jiang Y, Jin C, Sun B (2014) Soil aggregate stratification of nematodes and ammonia oxidizers affects nitrification in an acid soil. Environmental Microbiol 16: 3083-3094. doi: 10.1111/1462-2920.12339.

Laganiére J, Angers DA, ParÉ D (2010) Carbon accumulation in agricultural soils after afforestation: a meta-analysis. Global Change Biol 16: 439-453. doi: 10.1111/j.1365-2486.2009.01930.x.

Lal R (2004) Soil carbon sequestration impacts on global climate change and food security. Science 304: 1623-1627. doi: 10.1126/science.1097396.

Laskar AH, Yadava MG, Ramesh R (2016) Radiocarbon and Stable Carbon Isotopes in Two Soil Profiles from Northeast India. Radiocarbon 54: 81-89. doi: 10.2458/azu_js_rc.v54i1.15840.

Li X, Wang F, Cao Y, Peng S, Chen Y (2017) Soil carbon storage and its determinants in the forests of Shaanxi Province, China. Chinese Journal of Plant Ecology 41: 953-963. 
Liu S, Zhang W, Wang K, Pan F, Yang S, Shu S (2015) Factors controlling accumulation of soil organic carbon along vegetation succession in a typical karst region in Southwest China. Sci Total Environ 521-522: 52-58. doi: http://dx.doi.org/10.1016/j.scitotenv.2015.03.074.

Liu Y, Hu C, Hu W, Wang L, Li Z, Pan J, Chen F (2018a) Stable isotope fractionation provides information on carbon dynamics in soil aggregates subjected to different long-term fertilization practices. Soil Till Res 177: 54-60. doi: https://doi.org/10.1016/j.still.2017.11.016.

Liu Y, Liu W, Wu L, Liu C, Wang L, Chen F, Li Z (2018b) Soil aggregate-associated organic carbon dynamics subjected to different types of land use: Evidence from 13C natural abundance. Ecol Eng 122: 295-302. doi: https://doi.org/10.1016/j.ecoleng.2018.08.018.

Marin-Spiotta E, Silver WL, Swanston CW, Ostertag R (2009) Soil organic matter dynamics during 80 years of reforestation of tropical pastures. Global Change Biol 15: 1584-1597. doi: 10.1111/j.1365-2486.2008.01805.x.

Post WM, Emanuel WR, Zinke PJ, Stangenberger AG (1982) Soil carbon pools and world life zones. Nature 298: 156-159. doi: 10.1038/298156a0.

Qiu L, Wei X, Zhang X, Cheng J, Gale W, Guo C, Long T (2012) Soil organic carbon losses due to land use change in a semiarid grassland. Plant Soil 355: 299-309. doi: 10.1007/s11104-011-1099-x.

Qiu LP, Wei XR, Gao JL, Zhang XC (2015) Dynamics of soil aggregate-associated organic carbon along an afforestation chronosequence. Plant Soil 391: 
637

Richter DD, Markewitz D, Trumbore SE, Wells CG (1999) Rapid accumulation and turnover of soil carbon in a re-establishing forest. Nature 400: 56-58. doi: $10.1038 / 21867$

Rytter RM (2016) Afforestation of former agricultural land with Salicaceae species Initial effects on soil organic carbon, mineral nutrients, $\mathrm{C}: \mathrm{N}$ and $\mathrm{pH}$. Forest Ecol Manag 363: 21-30. doi: 10.1016/j.foreco.2015.12.026.

Schmidt MWI, Torn MS, Abiven S, Dittmar T, Guggenberger G, Janssens IA, Kleber M, Kogel-Knabner I, Lehmann J, Manning DAC, Nannipieri P, Rasse DP, Weiner S, Trumbore SE (2011) Persistence of soil organic matter as an ecosystem property. Nature 478: 49-56. doi: 10.1038/nature10386.

Shi WY, Du S, Morina JC, Guan JH, Wang KB, Ma MG, Yamanaka N, Tateno R (2017) Physical and biogeochemical controls on soil respiration along a topographical gradient in a semiarid forest. Agr Forest Meteorol 247: 1-11. doi: 10.1016/j.agrformet.2017.07.006.

Shi WY, Tateno R, Zhang JG, Wang YL, Yamanaka N, Du S (2011) Response of soil respiration to precipitation during the dry season in two typical forest stands in the forest-grassland transition zone of the Loess Plateau. Agr Forest Meteorol 151: 854-863. doi: 10.1016/j.agrformet.2011.02.003.

Shi WY, Yan MJ, Zhang JG, Guan JH, Du S (2014) Soil CO2 emissions from five different types of land use on the semiarid Loess Plateau of China, with emphasis on the contribution of winter soil respiration. Atmos Environ 88: 
74-82. doi: 10.1016/j.atmosenv.2014.01.066.

Shi WY, Zhang JG, Yan MJ, Yamanaka N, Du S (2012a) Seasonal and diurnal dynamics of soil respiration fluxes in two typical forests on the semiarid Loess Plateau of China: Temperature sensitivities of autotrophs and heterotrophs and analyses of integrated driving factors. Soil Biol Biochem 52: 99-107. doi: 10.1016/j.soilbio.2012.04.020.

Shi XH, Zhang XP, Yang XM, Drury CF, McLaughlin NB, Liang AZ, Fan RQ, Jia SX (2012b) Contribution of winter soil respiration to annual soil $\mathrm{CO}_{2}$ emission in a Mollisol under different tillage practices in northeast China (Vol 26, GB2007, doi: 2011GB004054). Glob Biogeochem Cycle 26: GB3020. doi: 10.1029/2012gb004477.

Sims PL, Bradford JA (2001) Carbon dioxide fluxes in a southern plains prairie. Agr $\begin{array}{llll}\text { Forest } & \text { Meteorol } & 109: & \text { 117-134. }\end{array}$ http://dx.doi.org/10.1016/S0168-1923(01)00264-7.

Six J, Paustian K (2014) Aggregate-associated soil organic matter as an ecosystem property and a measurement tool. Soil Biol Biochem 68: A4-A9. doi: https://doi.org/10.1016/j.soilbio.2013.06.014.

Snell HSK, Robinson D, Midwood AJ (2015) Tree species' influences on soil carbon dynamics revealed with natural abundance $13 \mathrm{C}$ techniques. Plant Soil 400: 285-296. doi: 10.1007/s11104-015-2731-y.

Song B-L, Yan M-J, Hou H, Guan J-H, Shi W-Y, Li G-Q, Du S (2016) Distribution of soil carbon and nitrogen in two typical forests in the semiarid region of the 
680

681

682

683

684

685

686

687

688

689

690

691

692

693

694

695

696

697

698

699

700

701

Loess Plateau, China. CATENA 143: 159-166. doi: https://doi.org/10.1016/j.catena.2016.04.004.

Spohn M, Chodak M (2015) Microbial respiration per unit biomass increases with carbon-to-nutrient ratios in forest soils. Soil Biol Biochem 81: 128-133. doi: http://dx.doi.org/10.1016/j.soilbio.2014.11.008.

Tan W, Zhou L, Liu K (2013) Soil aggregate fraction-based 14C analysis and its application in the study of soil organic carbon turnover under forests of different ages. Chinese Sci Bull 58: 1936-1947. doi: $10.1007 / \mathrm{s} 11434-012-5660-7$.

Tang X, Liu S, Liu J, Zhou G (2010) Effects of vegetation restoration and slope positions on soil aggregation and soil carbon accumulation on heavily eroded tropical land of Southern China. J Soil Sediment 10: 505-513. doi: 10.1007/s11368-009-0122-9.

Tateno R, Taniguchi T, Zhang J, Shi W-Y, Zhang J-G, Du S, Yamanaka N (2017) Net primary production, nitrogen cycling, biomass allocation, and resource use efficiency along a topographical soil water and nitrogen gradient in a semi-arid forest near an arid boundary. Plant Soil 420: 209-222. doi: 10.1007/s11104-017-3390-y.

Tateno R, Tokuchi N, Yamanaka N, Du S, Otsuki K, Shimamura T, Xue Z, Wang S, Hou Q (2007) Comparison of litterfall production and leaf litter decomposition between an exotic black locust plantation and an indigenous oak forest near Yan'an on the Loess Plateau, China. Forest Ecol Manag 241: 84-90. doi: 
703

Tisdall JM, Oades JM (1982) Organic matter and water-stable aggregates in soils. J Soil Sci 33: 141-163. doi: https://doi.org/10.1111/j.1365-2389.1982.tb01755.x.

Torn MS, Lapenis AG, Timofeev A, Fischer ML, Babikov BV, Harden JW (2002) Organic carbon and carbon isotopes in modern and 100-year-old-soil archives of the Russian steppe. Global Change Biol 8: 941-953. doi: 10.1046/j.1365-2486.2002.00477.x.

Torn MS, Swanston CW, Castanha C, Trumbore SE (2009) Storage and Turnover of Organic Matter in Soil. Biophysico-Chemical Processes Involving Natural Nonliving Organic Matter in Environmental Systems.

Trumbore SE (1993) Comparison of carbon dynamics in tropical and temperate soils using radiocarbon measurements. Glob Biogeochem Cycle 7: 275-290. doi: $10.1029 / 93 \mathrm{gb} 00468$.

van Straaten O, Corre MD, Wolf K, Tchienkoua M, Cuellar E, Matthews RB, Veldkamp E (2015) Conversion of lowland tropical forests to tree cash crop plantations loses up to one-half of stored soil organic carbon. P Natl Acad Sci USA: 201504628. doi: 10.1073/pnas.1504628112.

Wang F, Ding Y, Sayer EJ, Li Q, Zou B, Mo Q, Li Y, Lu X, Tang J, Zhu W, Li Z (2017) Tropical forest restoration: Fast resilience of plant biomass contrasts with slow recovery of stable soil C stocks. Funct Ecol 31: 2344-2355. doi: https://doi.org/10.1111/1365-2435.12925.

Wang K, Shao R, Shangguan Z (2010) Changes in spicies richness and community 
productivty during succession on the Loess Plateau(China). Pol J Ecol 58: 501-510.

Wei X, Huang L, Xiang Y, Shao M, Zhang X, Gale W (2014) The dynamics of soil OC and N after conversion of forest to cropland. Agr Forest Meteorol 194: 188-196. doi: https://doi.org/10.1016/j.agrformet.2014.04.008.

Wei XR, Shao MG, Gale WJ, Zhang XC, Li LH (2013) Dynamics of aggregate-associated organic carbon following conversion of forest to cropland. Soil Biol Biochem 57: 876-883. doi: 10.1016/j.soilbio.2012.10.020.

Yamamoto S, Endo T (2014) Soils on the Loess Plateau. In: A Tsunekawa, G Liu, N Yamanaka, S Du (eds) Restoration and Development of the Degraded Loess Plateau, China. Springer Japan, Tokyo.

Yamanaka N, Hou Q-C, Du S (2014) Vegetation of the Loess Plateau. In: A Tsunekawa, G Liu, N Yamanaka, S Du (eds) Restoration and Development of the Degraded Loess Plateau, China. Springer Japan, Tokyo.

Zhang J, Taniguchi T, Tateno R, Xu M, Du S, Liu G-B, Yamanaka N (2013) Ectomycorrhizal fungal communities of Quercus liaotungensis along local slopes in the temperate oak forests on the Loess Plateau, China. Ecol Res 28: 297-305. doi: 10.1007/s11284-012-1017-6.

Zhang KR, Dang HS, Zhang QF, Cheng XL (2015) Soil carbon dynamics following land-use change varied with temperature and precipitation gradients: evidence from stable isotopes. Global Change Biol 21: 2762-2772. doi: 10.1111/gcb.12886. 
746

747

748

749

750

751

752

753

754

755

756

757

758

759

760

761

762

763

764

765

766

767

Zhao Y-G, Liu X-F, Wang Z-L, Zhao S-W (2015) Soil organic carbon fractions and sequestration across a 150-yr secondary forest chronosequence on the Loess Plateau, China. $\quad$ CATENA 303-308. doi: https://doi.org/10.1016/j.catena.2015.05.028.

Zhou P, Wen A, Zhang X, He X (2013) Soil conservation and sustainable eco-environment in the Loess Plateau of China. Environ Earth Sci 68: 633-639. doi: 10.1007/s12665-012-1766-0.

Zhou WJ, An ZS, Lin BH, Xiao JL, Zhang JZ, Xie J, Zhou MF, Porter SC, Head MJ, Donahue DJ (1992) Chronology of the baxie loess profile and the history of monsoon climates in China between 17000 and 6000 years BP. Radiocarbon 34: $818-825$.

Zhu G, Shangguan Z, Deng L (2021) Dynamics of water-stable aggregates associated organic carbon assessed from delta $\mathrm{C}-13$ changes following temperate natural forest development in China. Soil Till Res 205: 104782. doi: https://doi.org/10.1016/j.still.2020.104782.

Zhu YZ, Cheng P, Yu SY, Yu HG, Kang ZH, Yang YC, Jull AJT, Lange T, Zhou WJ (2010) Establishing a firm chronological framwork for neolithic and early dynastic archaeology in the shangluo area, central China. Radiocarbon 52: 466-478.

Zou H, Liu G, Wang H (2001) The vegetation development in North Ziwulin forest region in last fifty years. Acta Botanica Boreali-Occidentalia Sinica 22: 1-8. 
Table 1 The characters of soil at $0-10 \mathrm{~cm}$ and $20-20 \mathrm{~cm}$ depth of the three land-use systems (AF, AR and NQ) in semiarid Loess Plateau of China $^{\mathrm{a}}$

\begin{tabular}{|c|c|c|c|c|c|c|c|}
\hline land-use system & depth & NQ & Paired-NQ ${ }^{b}$ & $\mathbf{A R}$ & Paired-AR & $\mathbf{A F}$ & Paired-AF \\
\hline \multirow{2}{*}{$\operatorname{SOC}(\%)$} & $0-10 \mathrm{~cm}$ & $3.32 \pm 0.42$ & $3.38 \pm 0.23$ & $1.71 \pm 0.19$ & $1.81 \pm 0.15$ & $0.99 \pm 0.09$ & $1.07 \pm 0.03$ \\
\hline & $10-20 \mathrm{~cm}$ & $1.27 \pm 0.11$ & $1.19 \pm 0.13$ & $0.87 \pm 0.12$ & $0.92 \pm 0.08$ & $0.81 \pm 0.02$ & $0.79 \pm 0.05$ \\
\hline \multirow{2}{*}{ Total N $(\%)$} & $0-10 \mathrm{~cm}$ & $0.26 \pm 0.02$ & $0.23 \pm 0.03$ & $0.18 \pm 0.01$ & $0.18 \pm 0.03$ & $0.10 \pm 0.01$ & $0.11 \pm 0.01$ \\
\hline & $10-20 \mathrm{~cm}$ & $0.12 \pm 0.02$ & $0.11 \pm 0.01$ & $0.09 \pm 0.01$ & $0.11 \pm 0.02$ & $0.09 \pm 0.02$ & $0.08 \pm 0.01$ \\
\hline \multirow{2}{*}{ Total P $\left(\mathrm{g} \mathrm{kg}^{-1}\right)$} & $0-10 \mathrm{~cm}$ & $0.62 \pm 0.05$ & $0.63 \pm 0.03$ & $0.69 \pm 0.07$ & $0.66 \pm 0.02$ & $0.59 \pm 0.05$ & $0.61 \pm 0.02$ \\
\hline & $10-20 \mathrm{~cm}$ & $0.66 \pm 0.01$ & $0.62 \pm 0.04$ & $0.67 \pm 0.05$ & $0.65 \pm 0.03$ & $0.61 \pm 0.01$ & $0.62 \pm 0.02$ \\
\hline \multirow{2}{*}{ Fast $\mathrm{K}\left(\mathrm{mg} \mathrm{kg}^{-1}\right)$} & $0-10 \mathrm{~cm}$ & $142.88 \pm 7.76$ & $137.53 \pm 6.33$ & $190.13 \pm 10.67$ & $197.19 \pm 9.86$ & $76.20 \pm 7.10$ & $82.37 \pm 5.99$ \\
\hline & $10-20 \mathrm{~cm}$ & $145.91 \pm 9.37$ & $141.21 \pm 8.92$ & $186.78 \pm 11.56$ & $192.18 \pm 10.45$ & $73.19 \pm 8.17$ & $80.15 \pm$ \\
\hline \multirow{2}{*}{$\mathrm{pH}$} & $0-10 \mathrm{~cm}$ & $8.23 \pm 0.11$ & $8.19 \pm 0.05$ & $8.45 \pm 0.04$ & $8.43 \pm 0.02$ & $8.48 \pm 0.12$ & $8.50 \pm 0.09$ \\
\hline & $10-20 \mathrm{~cm}$ & $8.09 \pm 0.10$ & $8.12 \pm 0.02$ & $8.36 \pm 0.09$ & $8.30 \pm 0.06$ & $8.43 \pm 0.10$ & $8.39 \pm 0.11$ \\
\hline \multirow{2}{*}{$\begin{array}{l}\text { Bulk Density (g } \\
\qquad \mathrm{mm}^{-3} \text { ) }\end{array}$} & $0-10 \mathrm{~cm}$ & $0.99 \pm 0.04$ & $1.02 \pm 0.05$ & $1.16 \pm 0.04$ & $1.13 \pm 0.05$ & $1.30 \pm 0.03$ & $1.28 \pm 0.02$ \\
\hline & $10-20 \mathrm{~cm}$ & $1.18 \pm 0.01$ & $1.16 \pm 0.03$ & $1.17 \pm 0.02$ & $1.15 \pm 0.02$ & $1.25 \pm 0.02$ & $1.27 \pm 0.04$ \\
\hline
\end{tabular}

a. AF: abandoned farmland; AR: black locust plantation; QF: natural oak forest.

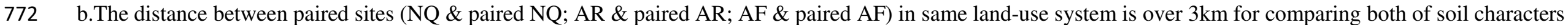
773 in the semiarid region. 
Table 2 The information on study sites of published studies ${ }^{\text {a }}$

\begin{tabular}{cccc}
\hline Conversion type & Land-use system & Distance $^{\mathrm{b}}$ & Reference \\
\hline Deforestation & Natural forest; Cropland & $>3 \mathrm{~km}$ & Wei et al. (2013) \\
& Farmland; Grass land; & & \\
Natural restoration & Natural forest & $\sim 5 \mathrm{~km}$ & Deng et al. (2013) \\
Deforestation & Natural forest; Cropland & $>3 \mathrm{~km}$ & Wei et al. (2014)
\end{tabular}

Natural \& artificial

Natural forest; Plantation $\quad>1.5 \mathrm{~km} \quad$ Song et al. (2016)

restoration

Farmland; Grass land;

Natural restoration

$>3 \mathrm{~km} \quad$ Deng et al. (2016)

Natural forest

Natural restoration $\quad$ Grass land; Natural forest $\quad>5 \mathrm{~km} \quad$ Zhu et al. (2021)

a. The published studies were carried out by using "space-for-time substitution" method in the same study area with current study.

777

b. Distance means the distance among different land-use systems 
Figure captions

Fig 1 Soil organic carbon (SOC) stock (a) and soil organic carbon contents (b) at each depth $(0-10 \mathrm{~cm}, 10-20 \mathrm{~cm}, 20-30 \mathrm{~cm}, 30-50 \mathrm{~cm}$ and $50-100 \mathrm{~cm})$ of the three different land-use systems. Error bars represent the standard error of the mean. Significant differences are indicated by the different letter $(p<0.05)$; AF: abandoned farmland; AR: artificial afforestation (plantation of Robinia pseudoacacia L); NQ: natural afforestation (natural forest - Quercus liaotungensis Koidz).

Fig 2 The different aggregate size OC stocks (a) and size class distributions (b) in the three land-use systems. Macroaggregates were $>0.25 \mathrm{~mm}$; microaggregatew were between 0.25 and $0.053 \mathrm{~mm}$; and silt \& clay were $<0.053 \mathrm{~mm}$. Error bars represent the standard error of the mean. Significant differences are indicated by different letter $(p$ $<0.05$ ); AF: abandoned farmland; AR: artificial afforestation (plantation of Robinia pseudoacacia L); NQ: natural afforestation (natural forest - Quercus liaotungensis Koidz).

Fig 3 The C:N and C:P of different soil aggregate size classes in the three land-use systems. Macroaggregates were $>0.25 \mathrm{~mm}$; microaggregatew were between 0.25 and $0.053 \mathrm{~mm}$; and silt \& clay were $<0.053 \mathrm{~mm}$. Error bars represent the standard error of the mean. Significant differences are indicated by the different letter $(p<0.05)$; AF: abandoned farmland; AR: artificial afforestation (plantation of Robinia pseudoacacia L); NQ: natural afforestation (natural forest - Quercus liaotungensis Koidz). 
800

801

802

803

804

805

806

807

808

809

810

811

812

813

814

815

816

817

818

819

820

821

Fig 4 SOC decomposition rate constants $\left(\mathrm{k}_{1}\right)$ and new SOC input rate $\left(\mathrm{kg} \mathrm{m}^{-2} \mathrm{yr}^{-1}\right)$ calculated with a ${ }^{13} \mathrm{C}$ model under (a) artificial and (b) natural afforestation. Error bars represent the standard error of the mean. Significant differences are indicated by the asterisk symbol $(* p<0.05)$.

Fig 5 SOC decomposition rate constants $\left(\mathrm{k}_{2}\right)$ calculated with a ${ }^{14} \mathrm{C}$ model for different land use types. Error bars represent the standard error of the mean. Significant differences are indicated by different letters $(p<0.05)$. AF: abandoned farmland; AR: artificial afforestation (plantation of Robinia pseudoacacia L); NQ: natural afforestation (natural forest - Quercus liaotungensis Koidz).

Fig 6 The mean annual soil $\mathrm{CO}_{2}$ emission over 4 years in the three land-use systems. Error bars represent the standard error of the mean. Significant differences are indicated by the different letter $(p<0.05)$; AR: artificial afforestation (plantation of

Robinia pseudoacacia L); NQ: natural afforestation (natural forest - Quercus liaotungensis Koidz).

Fig 7 Changes in SOC stocks in macroaggregates and microaggregates with afforestation under (a-b) artificial and (c-d) natural restoration. Macroaggregates were $>0.25 \mathrm{~mm}$; microaggregatew were between 0.25 and $0.053 \mathrm{~mm}$; and silt \& clay were $<0.053 \mathrm{~mm}$. Error bars represent the standard error of the mean. Significant differences are indicated by the asterisk symbol $\left({ }^{*} p<0.05\right)$; ns: no significant. AF: 
L); NQ: natural afforestation (natural forest - Quercus liaotungensis Koidz).

824 


\section{Conflict of Interest}

826 - All authors declare no conflict of interest.

827 


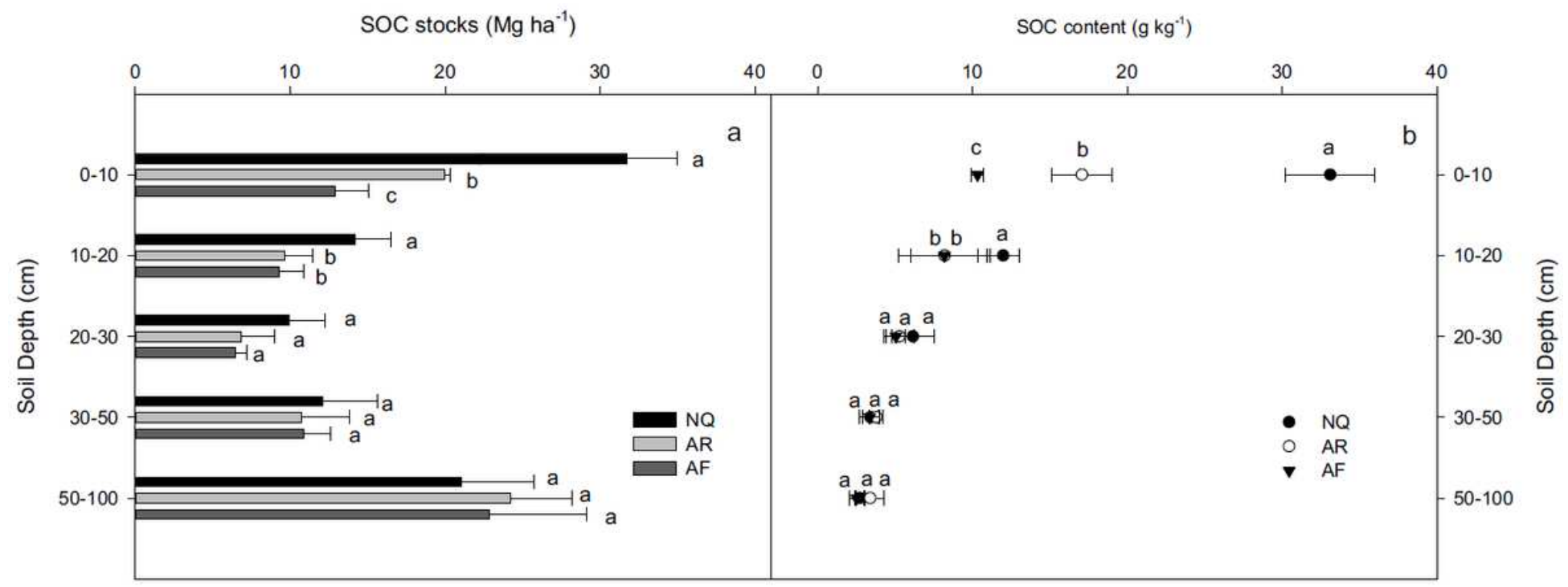

Figure 1

Soil organic carbon (SOC) stock (a) and soil organic carbon contents (b) at each depth $(0-10 \mathrm{~cm}, 10-20 \mathrm{~cm}$, $20-30 \mathrm{~cm}, 30-50 \mathrm{~cm}$ and $50-100 \mathrm{~cm}$ ) of the three different land-use systems. Error bars represent the standard error of the mean. Significant differences are indicated by the different letter $(p<0.05)$; AF: abandoned farmland; AR: artificial afforestation (plantation of Robinia pseudoacacia L); NQ: natural afforestation (natural forest - Quercus liaotungensis Koidz).

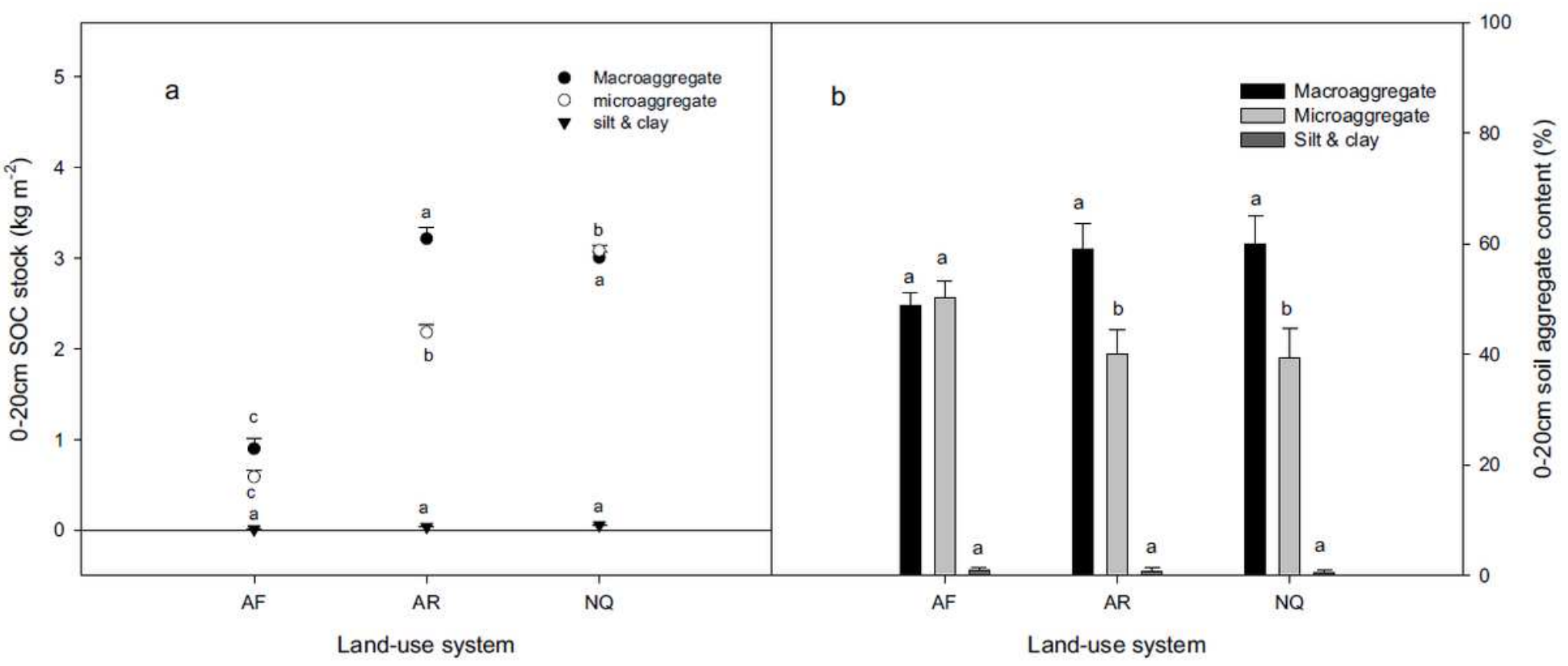

Figure 2 
The different aggregate size OC stocks (a) and size class distributions (b) in the three land-use systems. Macroaggregates were $>0.25 \mathrm{~mm}$; microaggregatew were between 0.25 and $0.053 \mathrm{~mm}$; and silt \& clay were $<0.053 \mathrm{~mm}$. Error bars represent the standard error of the mean. Significant differences are indicated by different letter ( $p<0.05)$; AF: abandoned farmland; AR: artificial afforestation (plantation of Robinia pseudoacacia L); NQ: natural afforestation (natural forest - Quercus liaotungensis Koidz).

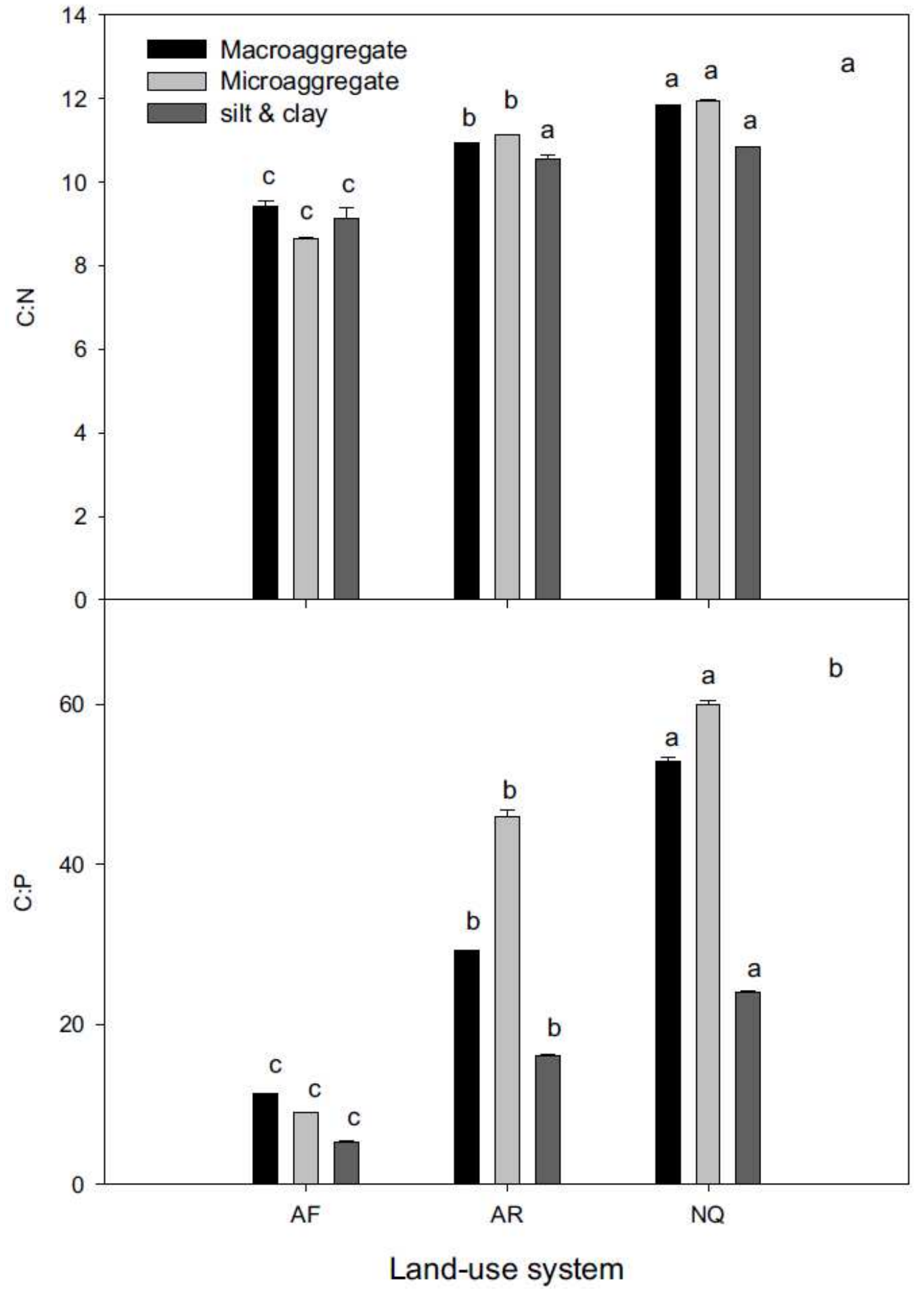

Figure 3 
The C:N and C:P of different soil aggregate size classes in the three land-use systems. Macroaggregates were $>0.25 \mathrm{~mm}$; microaggregatew were between 0.25 and $0.053 \mathrm{~mm}$; and silt \& clay were $<0.053 \mathrm{~mm}$. Error bars represent the standard error of the mean. Significant differences are indicated by the different letter $(p<0.05)$; AF: abandoned farmland; AR: artificial afforestation (plantation of Robinia pseudoacacia $L)$; NQ: natural afforestation (natural forest - Quercus liaotungensis Koidz).

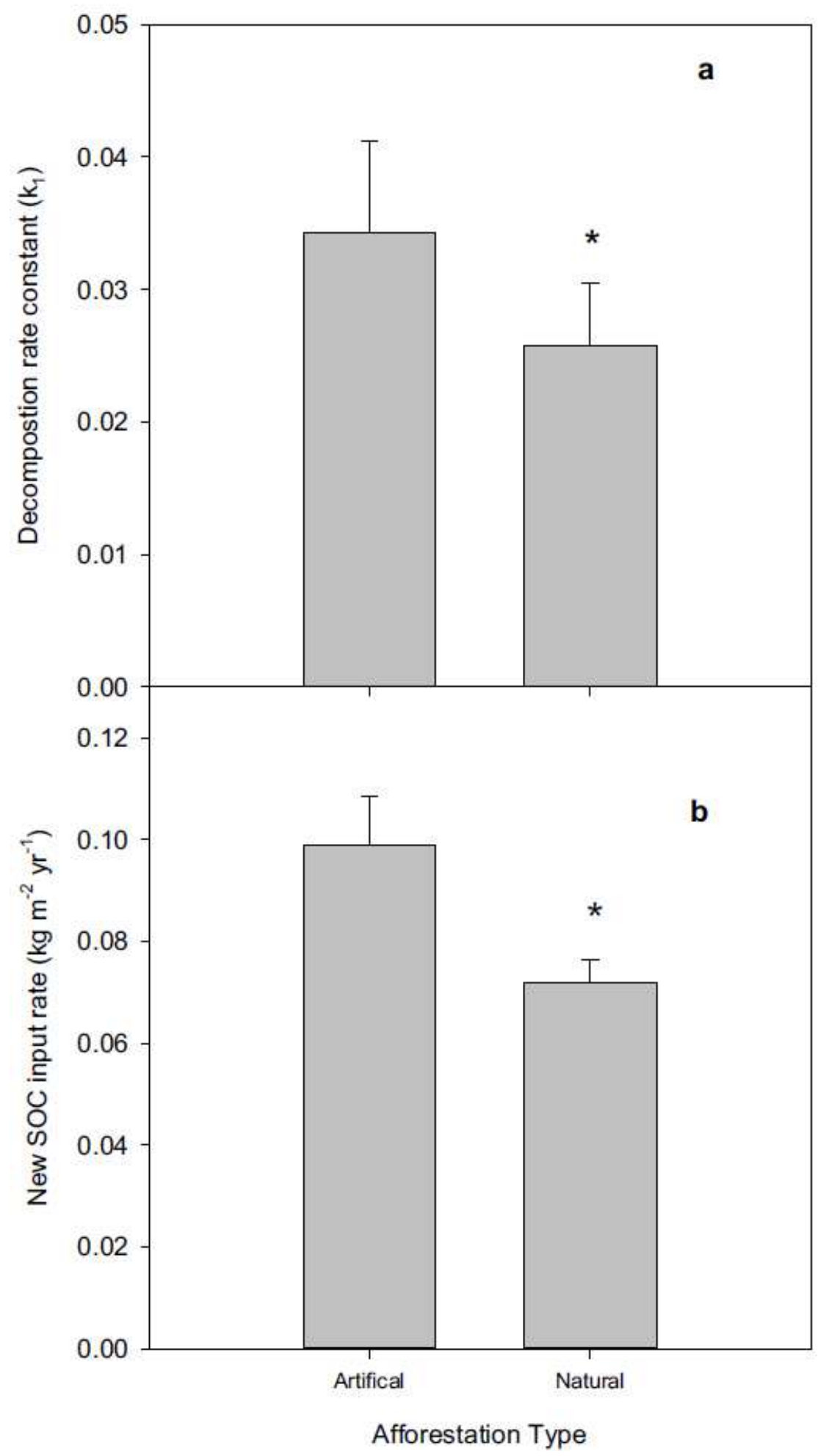

Figure 4 
SOC decomposition rate constants ( $\mathrm{k} 1$ ) and new SOC input rate ( $\mathrm{kg} \mathrm{m}-2 \mathrm{yr}-1)$ calculated with a 13C model under (a) artificial and (b) natural afforestation. Error bars represent the standard error of the mean. Significant differences are indicated by the asterisk symbol $\left({ }^{*} \mathrm{p}<0.05\right)$.

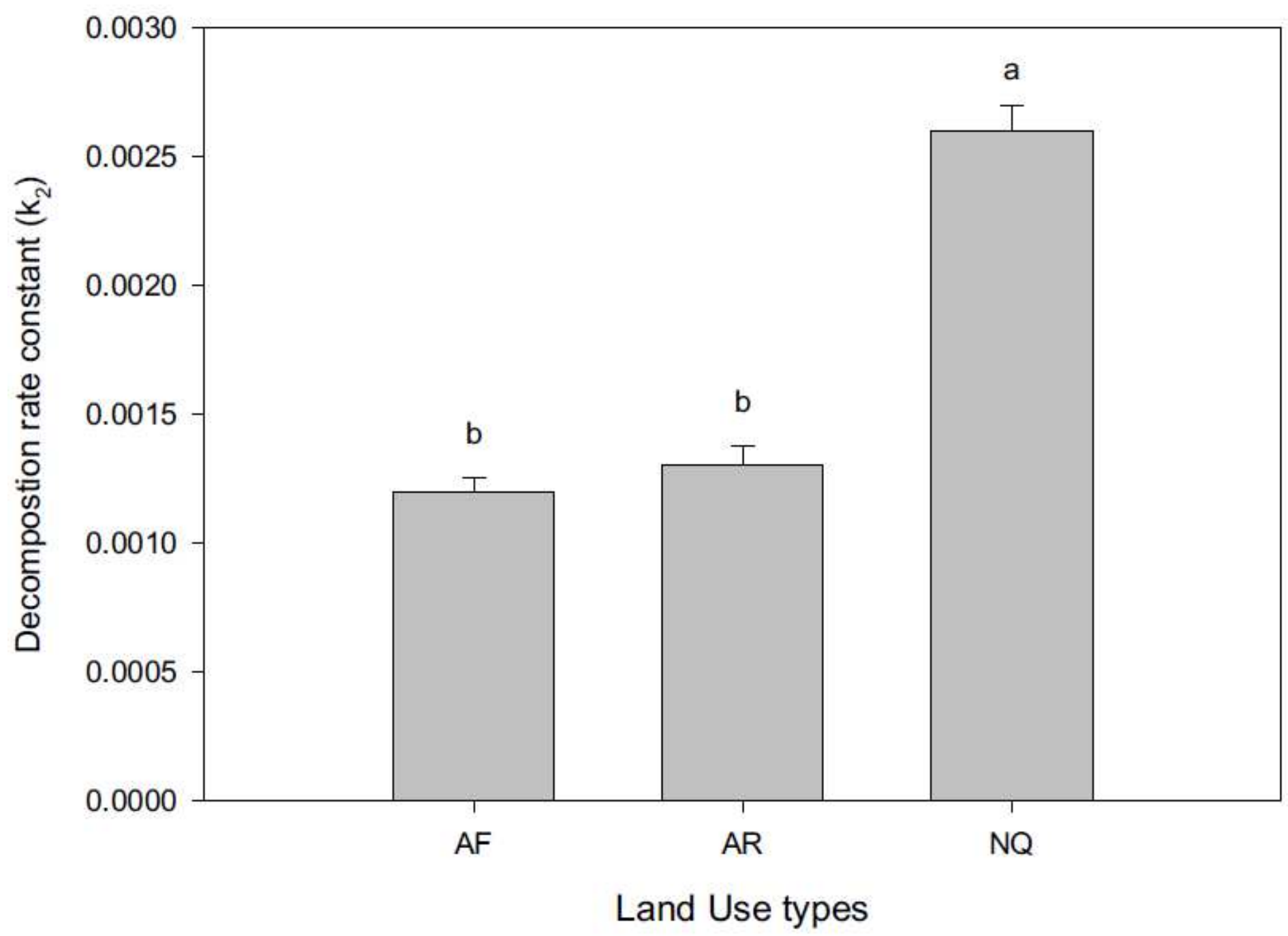

Figure 5

SOC decomposition rate constants (k2) calculated with a 14C model for different land use types. Error bars represent the standard error of the mean. Significant differences are indicated by different letters $(p<$ 0.05). AF: abandoned farmland; AR: artificial afforestation (plantation of Robinia pseudoacacia L); NQ: natural afforestation (natural forest - Quercus liaotungensis Koidz). 


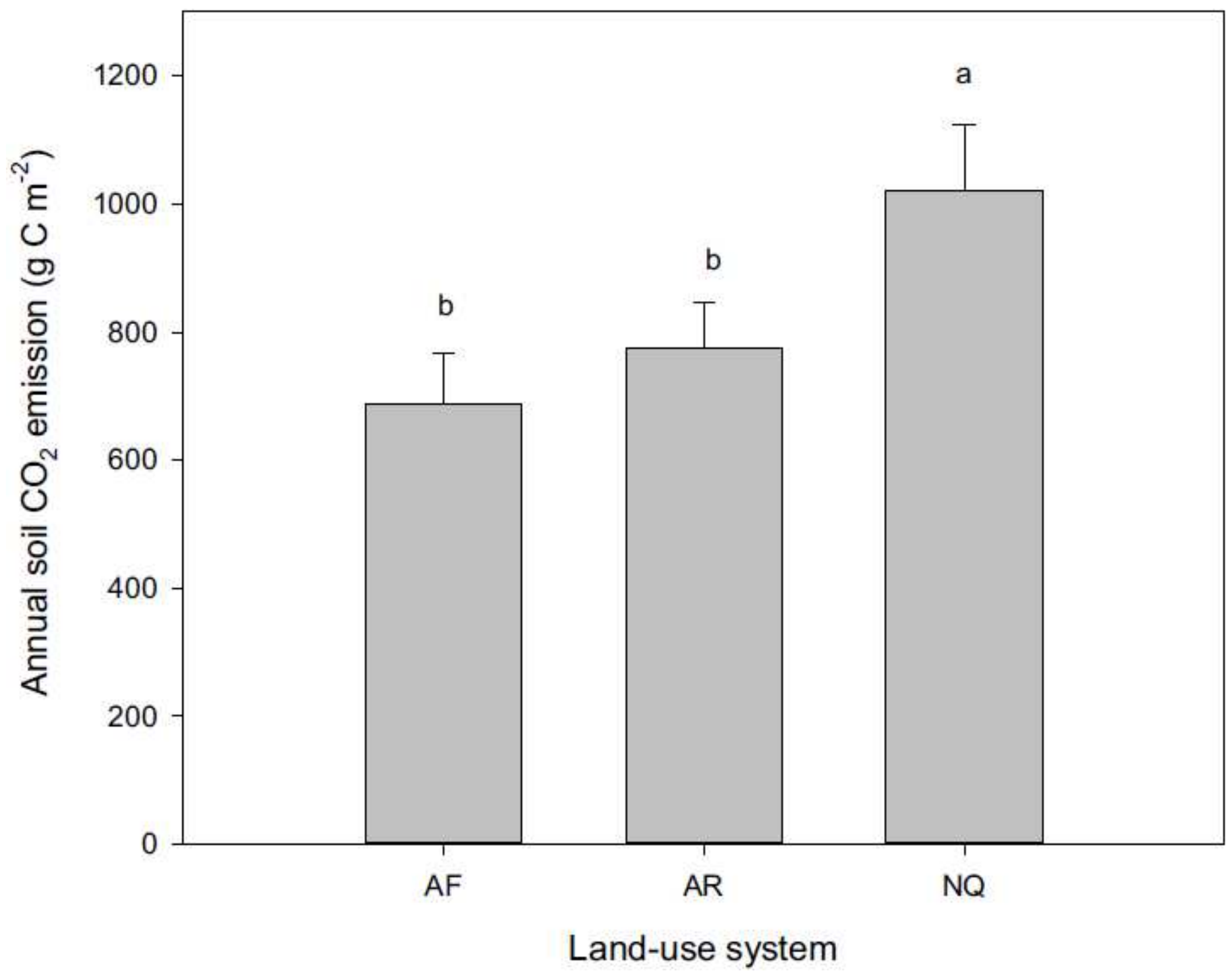

\section{Figure 6}

The mean annual soil $\mathrm{CO} 2$ emission over 4 years in the three land-use systems. Error bars represent the standard error of the mean. Significant differences are indicated by the different letter $(p<0.05)$; AR: artificial afforestation (plantation of Robinia pseudoacacia L); NQ: natural afforestation (natural forest Quercus liaotungensis Koidz). 


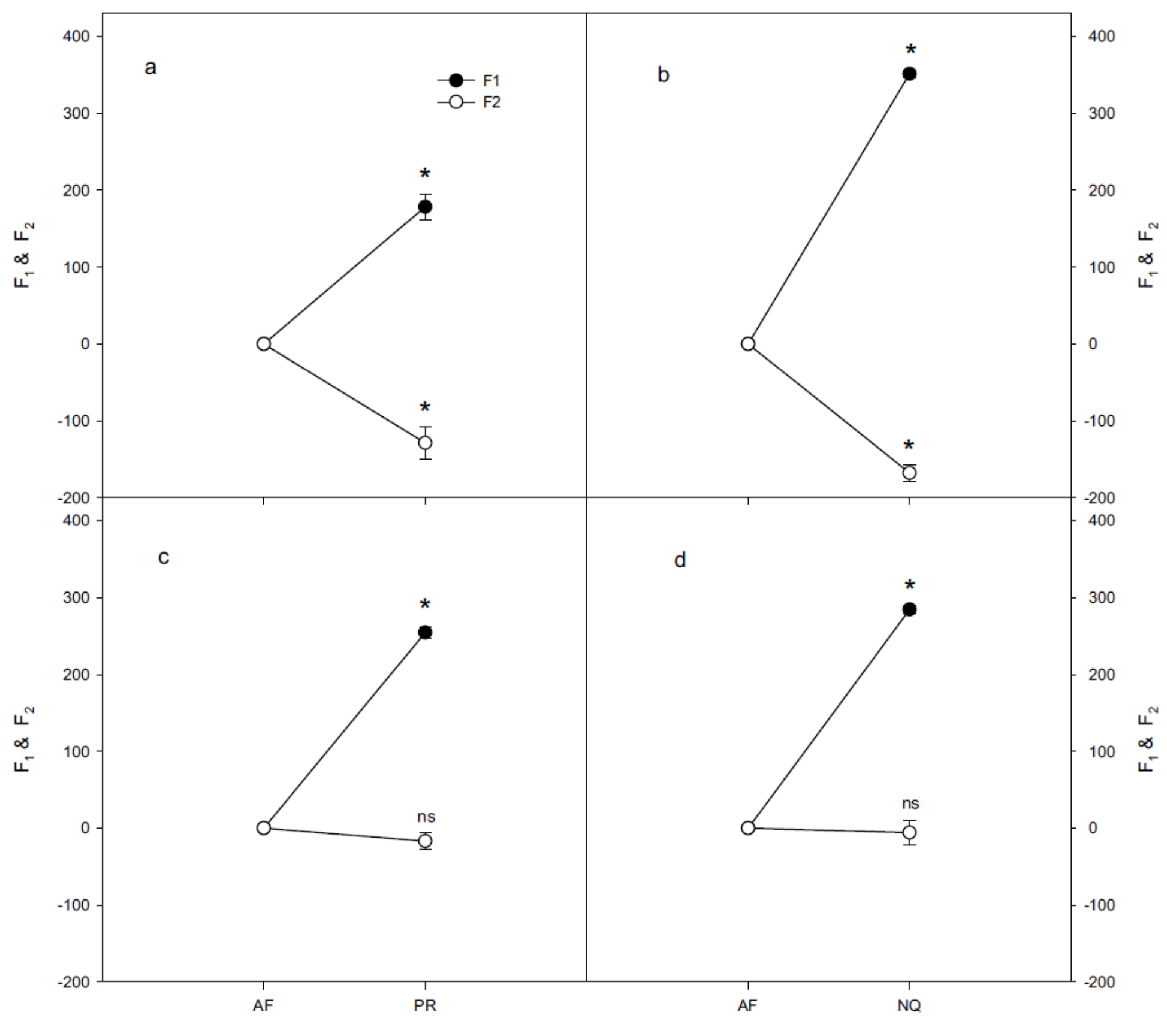

Artifical Afforestation

Natural Afforestation

Figure 7

Changes in SOC stocks in macroaggregates and microaggregates with afforestation under (a-b) artificial and (c-d) natural restoration. Macroaggregates were $>0.25 \mathrm{~mm}$; microaggregatew were between 0.25 and $0.053 \mathrm{~mm}$; and silt \& clay were $<0.053 \mathrm{~mm}$. Error bars represent the standard error of the mean.

Significant differences are indicated by the asterisk symbol ( $\left.{ }^{*} \mathrm{p}<0.05\right)$; ns: no significant. AF: abandoned farmland; AR: artificial afforestation (plantation of Robinia pseudoacacia L); NQ: natural afforestation (natural forest - Quercus liaotungensis Koidz). 